\title{
Organic Farming Versus Interest of the State for its Support
}

\author{
Lucia Palšová* \\ Department of Law, Faculty of European Studies and Regional Development, \\ Slovak University of Agriculture in Nitra, Nitra, Slovak Republic
}

Received: 5 April 2018

Accepted: 3 July 2018

\begin{abstract}
Industrialization of agriculture is associated with the creation of negative externalities of intensive agriculture. The situation has developed pressure to create alternatives to intensification, such as organic farming, which role is defined in Council Regulation (EC) No. 834/2007: consumer demand for healthy and safe food and the public interest in protecting the environment and the interest of the state in the health of its inhabitants, even though organic farming is a minor alternative and is necessary to support conditions for its existence. The aim of this paper is to evaluate the implementation of state support in the field of organic farming from legislative, political, institutional and financial perspectives, and to identify the main incentives as well as the barriers to the development of organic farming. In this paper we used in particular qualitative methods of survey (interviews with relevant stakeholders). In order to get a holistic picture, an analysis of the economic situation of organic farmers was conducted based on the available data. Based on the results of the paper it can be stated that although farmers have an interest in producing their products (plants and animals) in organic farming, the Slovak Republic has not created sufficient conditions to increase the share of organic farming in agriculture.
\end{abstract}

Keywords: organic farming; agriculture; Slovak Republic; support, sustainable development

\section{Introduction}

Nowadays, there is the prevailing opinion that modern farming practices have an adverse effect on organisms and the environment [1]. The fatal flaw of today's food production is that it is modelled on the industrial system. It does not attempt to remain within the bounds of nature but is rather designed to 'beat' nature - with technology, cheap labour and externalization of costs [2].

$\overline{\text { *e-mail: lucia.palsova@uniag.sk }}$
Intensive agriculture is a result of a natural development. It has been particularly affected by technical progress. The period between the two world wars is associated with the decline of agriculture and rural areas and has led to a crisis whose consequences have been addressed by industrial agriculture. Measures of industrial farming have also caused irreversible environmental and socio-economic implications over the coming decades. As a consequence, maintaining conventional agriculture is bringing still greater intensification and development of the bio-tech industry (Fig. 1). At the beginning, the incentive was to remove a shortage on the market after the war. Currently, this development is driven mainly by market mechanisms 


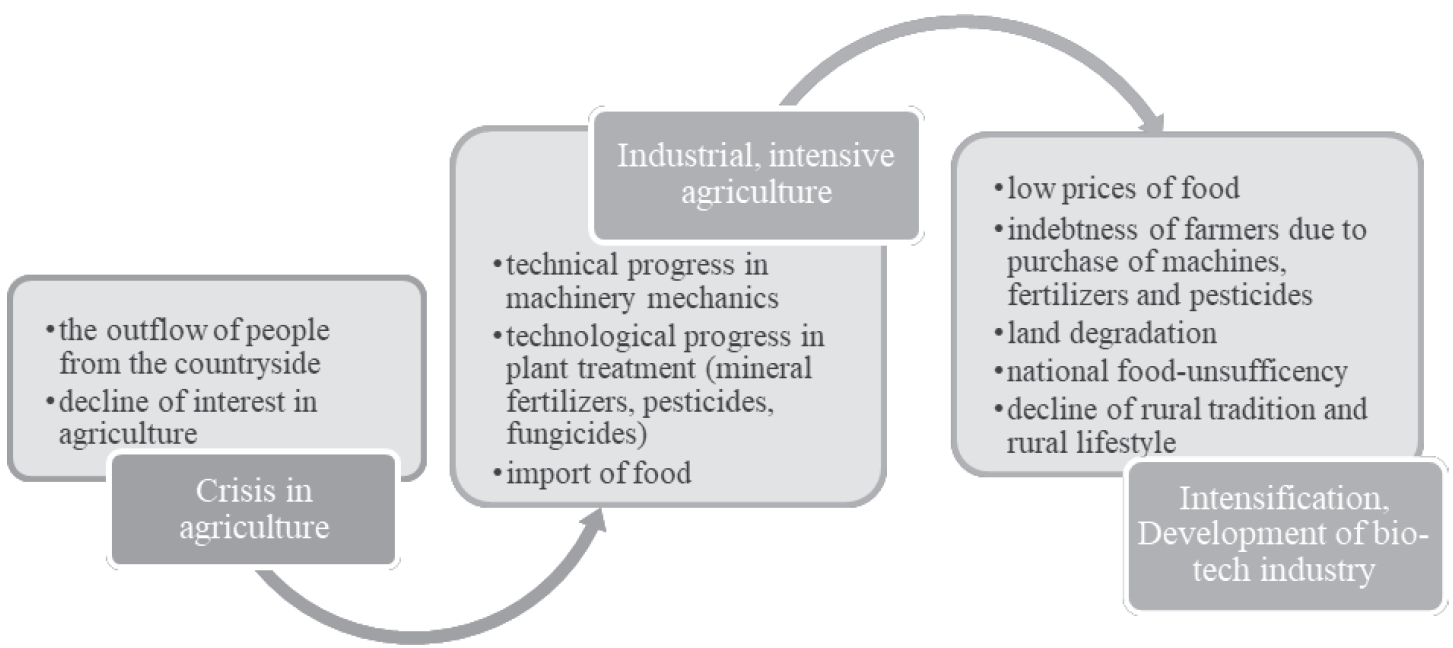

Fig. 1. Development of agriculture.

- reaching continuously higher economic effectiveness to maintain position in the EU market; and regarding input costs, EU farmers are not able to compete with suppliers from other continents.

As Fig. 1 indicates, there are negative externalities associated with the industrialization of agriculture. Such a situation developed pressure on the creation of alternatives to intensification, such as organic farming [3].

Organic farming is considered a holistic production management system that promotes and enhances agro-ecosystem health, including biodiversity, biological cycles and soil biological activity. It emphasizes the use of management practices in preference to the use of off-farm inputs, taking into account the fact that regional conditions require locally adapted systems [4]. Organic farming needs to respect four principles:

- Health - organic farming should sustain and enhance the health of soil, plants, animals, humans and the planet as being one and indivisible.

- Fairness - organic agriculture should build on relationships that ensure fairness with regard to common environment and life opportunities.

- Care - organic farming should be managed in a precautionary and responsible manner to protect the health and well-being of current and future generations and the environment.

- Ecology - organic farming should be based on living ecological systems and cycles, work with them, emulate them and help sustain them [5].

The path to the development of organic farming follows the main steps:

1) Establishing the organic farming community.

2) Political recognition of organic farming standards and certification as a basis for distributing products and recruiting farmers.

3) Introducing financial support for organic farmers.

4) Positive involvement of general farmer organisations.

5) Developing organic food market mechanisms.
6) Establishing an institutional setting in the form of administrative committee, umbrella organisation, advisory board or other type of discussion arena to facilitate the necessary coordination among the farming community, agricultural policy and the food market [9].

Some authors (e.g., [2]) also add another aspect of organic farming, which is fair access to the means of food production while receiving a fair return for their labour, and consumers have food they can trust at fair prices.

Within the council regulation [6], the European Union defines, in particular, two roles of organic farming: consumer demand for healthy and safe food and the public interest in protecting the environment (soil protection, biodiversity protection, animal welfare), and the interest of the state in the health of its inhabitants. These features partially reflect the negative externalities of intensive agriculture. On the other hand, there are no studies significantly proving that organic farming, as a system, would be competitive in the market compared to intensive agriculture without national support [7-8].

Within the given intention, this paper deals with the analysis of conditions for functioning of organic farming in Slovakia, which are set up by the state (leadership, policy, financial support).

Although the Slovak Republic has good potential for the development of organic farming, there is a lack of deeper research of the conditions of functioning of organic farming. Therefore, the aim of this paper is to evaluate the implementation of state support in the field of organic farming from legislative, political, institutional and financial perspectives as a path to the development of organic farming [9], and to identify the main incentives as well as the barriers to the development of organic farming. The results of the paper will contribute to the expert discussion on the issue, to raise the issue faced by organic farmers and to suggest possible directions for improving the functioning of organic farming. 


\section{Materials and Methods}

This paper uses results of the research conducted by the Department of Law of the Faculty of European Studies and Regional Development, Slovak University of Agriculture in Nitra [10], information from available professional literature and statistical data from the Central Control and Testing Institute in Agriculture (CCTIA), Agricultural Paying Agency (APA) and EUROSTAT.

Further supporting research is based on interviews with organic farmers, who were:

1) Original entities: entities acting on the supply side (organic farmers) and demand side (processors, traders).

2) Subsidiary entities that directly/indirectly create conditions affecting the functioning of organic farming: CCTIA and APA.

In order to get a holistic picture, an analysis of the economic situation of organic farmers was conducted based on the secondary data.

According to data published on the USKSUPs website (register of operators dealing with the production of unprocessed agricultural products and livestock farming in organic agricultural production and in organic agricultural production in conversion), 438 organic primary producers and organic primary producers in the conversion were registered as of 31.09.2017. During the survey process, 222 organic farmers $(50.2 \%$ of registered organic farmers) were interviewed by telephone, out of which 141 organic farmers answered questions, representing $32.19 \%$ of all organic primary producers and organic primary producers in conversion; 67 selected organic farmers did not have an existing telephone number on the CCTIA website and 14 organic farmers refused to participate in the questionnaire survey. The percentage of surveyed organic farms represents an evenly spaced percentage for all regions of the Slovak Republic. The legal form and size of the business were irrelevant for purposes of the survey.

Organic farmers were asked to answer open questions with sub-questions concerning the following topics:

- Their motivation to enter and stay in the organic farming system.

- How they are supported by the state.

- The method of placing products on the market and market potential of organic products on the Slovak and EU markets.

In order to find out the financial support for organic farmers, data on beneficiaries from APA's database ${ }^{1}$ for the years 2015 and $2016^{2}$ were used (409 organic farmers were surveyed).

Beneficiaries published on the APA website: http://www.apa. sk/prijimatelia-pomoci

2 The year 2017 had not yet been processed by the APA
Financial conditions of organic farmers ${ }^{3}$ were analyzed using the financial data available at the websites finstat.sk and zisk.sk, in which the revenues and earnings averaged over the period 2013-2017 were tracked (294 organic farmers were analyzed).

Within primary research, 7 demand subjects of organic farming were interviewed, namely: 4 retail chains (BILLA, LIDL, KAUFLAND and CONRAD) and 3 traders operating organic shops. The aim of the survey was to determine the interest of consumers in organic products, what percentage of organic products are of a Slovak origin and what measures they do to promote organic farming.

In order to provide a comprehensive overview of the promotion of organic farming, the Union of Organic Farming (EKOTREND), as the largest association of organic farmers in the Slovak Republic, was also interviewed. The aim was to identify, in particular, the motivation of the members of the Union to carry out organic farming, and the main incentives and barriers to the development of organic farming.

The analysis of the above surveys, along with the available secondary resources, helped us draw a picture of the current support for organic farming in the Slovak Republic. Based on the findings, possible improvements in support for organic farming are formulated in the conclusions.

\section{Results and Discussion}

The paper is structured thus: Section 1 development of organic farming in the SR, while Section 2 is concerned with development of organic farming production. Issues regarding assessment of the conditions (legislative, institutional, financial) of the organic farming are discussed in Section 3, Sections 4 and 5. Section 6 deals with motivational incentives and barriers of the development of organic farming. Section concludes the paper, focussing on some of the key issues in the debates about the conditions of organic farming in the Slovak Republic.

\section{Development of Organic Farming}

In the Slovak Republic, organic farming started to develop 15-20 years later than in other European countries, with the concept of organic farming being taken mainly from German schools [11]. According to [12], the Slovak Republic has good potential for the development of organic farming in terms of soil geography and soil quality - both in plant and livestock production.

A significant increase of organic farming was due to the fulfilment of the Slovak Republic's commitment

Financial statement of natural persons/entrepreneurs is never disclosed in the register of financial statements 
Table 1. Farmer running organic farming as of 31.09.2017.

\begin{tabular}{|c|c|c|c|c|c|c|c|c|}
\hline Region & BA & TT & NR & TN & BB & ZA & PO & KE \\
\hline Number of organic farmers & 15 & 21 & 29 & 30 & 81 & 49 & 101 & 59 \\
\hline Percentage of organic farmers in region & 3.9 & 5.5 & 7.5 & 7.8 & 21 & 12.7 & 26.2 & 15.3 \\
\hline Number of organic farmers in conversion & 5 & 1 & 11 & 3 & 15 & 3 & 7 & 8 \\
\hline Percentage of organic farmers in conversion in region & 9.4 & 1.9 & 20.8 & 5.7 & 28.3 & 5.7 & 13.2 & 15.1 \\
\hline
\end{tabular}

(BA - Bratislava Region, TT - Trnava Region, NR - Nitra Region, TN - Trenčín Region, BB - Banská Bystrica Region, ZA - Žilina Region, PO - Prešov Region, KE - Košice Region)

to the EU, which was implemented through the Rural Development Programme for 2004-2006 [13] and 2007-2013 [14], when the organic agricultural production area was determined to be at least $5 \%$ of the total area of agricultural land [15]. Based on the data from the CCTIA as of 31.12.2013, the area of organic farming production was $162,028.78$ hectares $(8.06 \%)$. It can be concluded that the regulatory stimulation by the state for the introduction of organic farming has helped to develop organic farming in the Slovak Republic.

In the 2014-2020 programming period, the Slovak Republic set a goal of maintaining 135340 hectares cultivated in organic farming (i.e., $5.7 \%$ of the total agricultural land calculated as of $31.01 .2017,[16]$ ) and 15,000 ha to be converted from conventional farm management to organic form of land management in a registered and controlled organic farming system $(0.63 \%$ of the area of agricultural land).

In Slovakia, there are currently 385 organic farmers and 53 organic farmers in conversion, who operate in the following legal forms: cooperative (77), limited liability company (205), joint stock company (9), self-employed farmer (141) and others (6).

Individual regions of Slovakia have different potential for establishing and developing organic farming
(Table 1). This results in a different representation of organic farmers within the regions dominated by the Prešov Region and the Banská Bystrica Region; on the contrary, the lowest number of organic farmers is located in the Bratislava and Trnava regions. This fact stems from the natural conditions of the SR. In the Prešov, Žilina, Banská Bystrica and Košice regions, the vast majority of the agricultural land is permanent grasslands of lower quality. For farmers it is therefore easier to decide on production in organic farming, especially in livestock production.

Data of CCTIA from 1991 to 2017 show that most organic farmers started with organic farming naturally in the period when it was expected to increase the funds for organic farming under the new EU programming period, in 2004-2005; 2008-2009 and 2014-2015 [17]. This means that the financial stimulation itself as well as its positive expectation created a positive effect for the creation of organic farmers.

On the contrary, it can be considered negatively that on average $56.1 \%$ of organic farmers who were included in organic production in 2004-2016 requested CCTIA for the cancellation of registration of organic operators; in 2004-2013, $64.28 \%$ of farmers requested the cancellation of organic farming and an average of

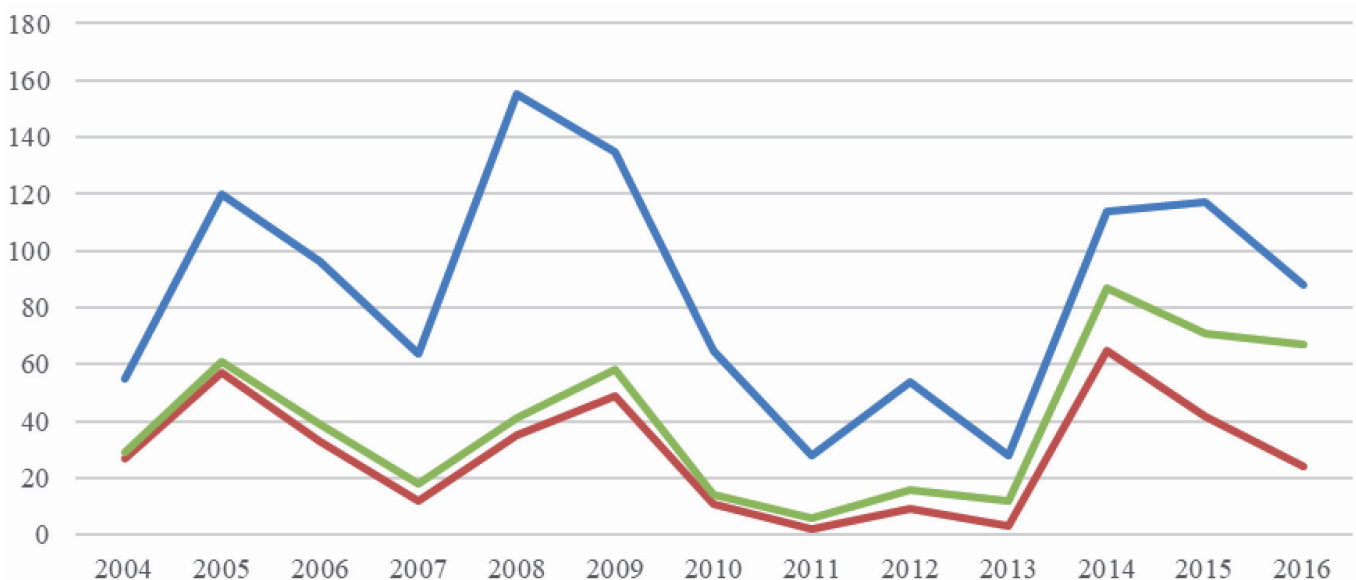

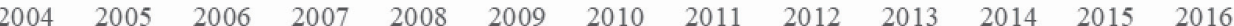

- Number of issued registration of the organic farmers

- Number of organic farmer in plant and animal production

Total amount of organic producers

Fig. 2. Development of the registration of organic farmers. 
Table 2. Organic farmers in terms of production (2017)

\begin{tabular}{|c|c|c|c|c|c|c|c|c|}
\hline \multirow{2}{*}{ Region } & \multicolumn{4}{|c|}{ Plant production } & \multicolumn{4}{c|}{ Plant and animal production } \\
\cline { 2 - 9 } & Organic farmers & Organic farmers in conversion & Organic farmers & \multicolumn{2}{c|}{ Organic farmers in conversion } \\
\hline Bratislava & 9 & $60.00 \%$ & 5 & $100.00 \%$ & 6 & $40.00 \%$ & - & - \\
\hline Trnava & 11 & $52.38 \%$ & 1 & $100.00 \%$ & 10 & $47.62 \%$ & - & - \\
\hline Nitra & 25 & $86.21 \%$ & 8 & $72.73 \%$ & 4 & $13.79 \%$ & 3 & $27.27 \%$ \\
\hline Trenčín & 5 & $16.67 \%$ & 1 & $33.33 \%$ & 25 & $83.33 \%$ & 2 & $66.67 \%$ \\
\hline Banská Bystrica & 8 & $9.88 \%$ & 3 & $20.00 \%$ & 73 & $90.12 \%$ & 12 & $80.00 \%$ \\
\hline Žilina & 5 & $10.20 \%$ & 1 & $33.33 \%$ & 44 & $89.80 \%$ & 2 & $66.67 \%$ \\
\hline Prešov & 5 & $4.95 \%$ & 1 & $14.29 \%$ & 96 & $95.05 \%$ & 6 & $85.71 \%$ \\
\hline Košice & 4 & $6.78 \%$ & 3 & $37.50 \%$ & 55 & $93.22 \%$ & 5 & $62.50 \%$ \\
\hline Total & 72 & $18.70 \%$ & 23 & $43.40 \%$ & 313 & $81.30 \%$ & 30 & $56.60 \%$ \\
\hline
\end{tabular}

The percentage share means the percentage share of all organic farmers/organic farmers in conversion in the Slovak republic.

$28.95 \%$ in 2014-2016. The difference between the periods is given by way of regulation of the five-year commitment of organic farming within the framework of the measures of the Rural Development Programme $2014-2020$ as regulated by $\S 31$ et seq. Government Regulation No. 75/2015 Coll. Laying down the rules for the provision of support in connection with the measures of the rural development programme, as amended. This analysis shows that despite their discontent, organic operators tend to complete the 5-year commitment; otherwise, they are required to be sanctioned in accordance with Article 38 of Regulation No. 75/2015 Coll.

This result points to the fact, that although financial incentives can motivate the establishment of organic operators, conditions in the Slovak Republic cannot stimulate the sustainability of their existence.

\section{Development of Organic Farming Production}

Despite the fact that more than $80 \%$ of all organic farmers are engaged in organic animal production, in the new programming period 2014-2020, the Slovak Republic decided to financially stimulate only organic farmers carrying out plant production. The state's decision not to support organic animal production was not explained in the conceptual documents, nor was it justified in terms of analysis (Table 2), which disturbed the continuity of the organic farming support system. Nevertheless, the state's decision led to a reduction in the number of organic farmers in animal production by an average of $24.70 \%$, including regions which are traditionally involved in their organic animal production (Košice, Žilina and Prešov).

From the point of view of production, organic farmers can decide whether to carry out plant or animal production within the framework of organic production, but farmers carrying out animal production must also be involved in plant production. Only $18.70 \%$ of organic farmers are dealing exclusively with organic plant primary production in the Slovak Republic. They are concentrated in the Nitra, Trnava and Bratislava regions. On the other hand, predominant organic animal production combined with plant organic production is the predominant form, mainly in the Prešov, Košice, Banská Bystrica, Žilina and Trenčín regions. This is mainly due to natural conditions (e.g. slopes in the terrain, localization in protected areas) and the prevalence of permanent grassland, where organic farming is natural [18], and loss of yields in organic production compared to conventional production is not so significant.

\section{Legislative and Political Support for Organic Farming}

This chapter covers the development of Slovak as well as EU legislation dealing with organic farming. The analysis points out the vague attitude of state policy toward this area, which mostly copies the EU requirements and does not show deeper interest resulting in a situation when the policy and legislation do not reflect the specific Slovak conditions, and the continuity of the support is threatened.

A milestone in the development of organic farming in Slovakia was the entry of the Slovak Republic into the EU. Currently, force Regulation (EC) No. 834/2007 on organic production and labelling of organic products and repealing Regulation (EEC) No. 2092/91 entered into force on 1 January 2009.

The main objective of the Regulation was to ensure simplification and overall consistency, in particular to lay down the principles for harmonizing standards and, where appropriate, reducing the level of detail.

This EU regulation brings a harmonized concept of organic farming in the EU, with an emphasis on comprehensive soil management for organic production and animal production. However, it also encourages 
states to promote, in particular, the introduction of new techniques and substances more suitable for organic production, as well as the removal of administrative barriers to the development of organic farming in ensuring fair competition and the proper functioning of the internal market in organic products, as well as maintaining and satisfying consumer confidence in products labelled "organic."

In regards with adoption of Council Regulation (EC) No. 834/2007, in Slovakia Act No. 189/2009 Coll. on organic production of agricultural products was adopted.

Act No. 189/2009 Coll. can be assessed as a rule largely copying Council Regulation (EC) 834/2007, and it complements the institutional framework in the Slovak Republic. It can be considered as negative that the legal regulation of organic farming has only a minimal link to other legislation and conceptual documents that could directly or indirectly stimulate the development of organic farming.

The absence of state's interest in supporting organic farming is also reflected in the conceptual documents of the state in relation to agriculture. In programming period 2014-2020, the Concept of Development of Slovak Agriculture for 2013-2020 has been adopted by the state. It declares that the main interest of the state is the development of productive and competitive agriculture, ensuring economical use of agricultural land, sufficient production capacity of agriculture of the Slovak Republic in main agricultural commodities, food safety and accessibility for the population and ensuring sustainable forest management [19]. In spite of the state's declared effort on ecological stability, the whole text of the concept does not mention organic agriculture or minimal state support for environmental approaches in agriculture. The Action Plan for the Development of Slovak Agriculture for 2014-2020, which meets the concept of specific activities of the state, contains some areas of support in which organic farming could be supported (e.g., support of the processing industry). But in fact, none of these aids is implemented in relation to organic farming.

According to the binding act of the Rural Development Program 2014-2020, an Action Plan for the Development of Organic Farming by 2020 should be adopted in 2015, but this has not yet been adopted.

Resulting from the above-mentioned factors, in the programming period 2014-2020 it may be observed that the state's incentive to promote organic farming decreases. This is reflected in the legislative area by the absence of a supportive legal regulation for organic farming, particularly in the area of business support (e.g., environmental relief, sales promotion, etc.) as well as the absence of an organic farming concept for the future ${ }^{4}$.

In the previous period, organic farming was included in several conceptual documents, including the National

\section{Institutional Support for Organic Farming}

The institutional framework of organic farming is represented by:

1) EU authorities.

2) Government bodies: Ministry of Agriculture and Rural Development of the SR ( $\$ 3$ of the Act No. 189/2009 Coll.); Central Control and Testing Institute of Agriculture ( $\$ 4$ of the Act No. 189/2009 Coll.).

3) Inspection and certification organization in organic farming ( $\$ 3$ of the Act No. 189/2009 Coll.): Naturalis SK, Ltd. company (code: SK-BIO-002; with approval issued by CCTIA for the period from 26.05.2016 to 17.12.2019); BIOKONT CZ, Ltd. company (code: SK-BIO-003; with approval issued by CCTI for the period from 18.12.2014 to 16.12.2019).

4) Advisory bodies in the field of organic farming: Agroinštitút Nitra, state enterprise (within the advisory, it provides training for agricultural advisors in the field of agriculture and forestry and management of the public portal of agricultural advisors for the programming period 2014-2020; organizes a specific course ("Organic Farming: Effects on Quality and Efficiency of Plant Production") that was organized only once in the programming period 2014-2020); Independent agricultural consultants 5 (currently, only one organic farming advisor is registered for only two districts (Trebišov, Michalovce) in the Košice Region); Scientific research and departmental institutions (National Agricultural and Food Centre - Research Institute of Plant Production, Slovak Agriculture and Food Chamber, universities, vocational schools, etc.); Environmental advisory [20] is primarily funded as a government service paid by taxpayers. The advisory system is secondarily supported by the EU funds, as well as by national organizations and non-governmental organizations and by the personal resources of users [21].

5) The third sector is represented by EKOTREND an association of organic farming, which focuses its activities on promotion and education of organic farming outwards and ensures professional activities for its members.

From the point of view of the assessment of the institutional coverage of organic farming, it is possible to conclude only a formalized covering of organic farming in the interests of compliance with EU legal acts. Interviewing organic farmers and EKOTREND shows that no additional support for organic farming is initiated or implemented by the state authorities.

Strategic Reference Framework 2007-2013 and the Concept of Organic Farming Development by 2010

Independent consultants are certified in accordance with the Directive on Certification of Advisors and the Management of the Central Register of Agricultural Advisors of the Slovak Republic. 
Based on the research of the International Federation of Organic Agriculture Movements, in countries where organic farming is institutionally well documented there is constant market growth and the expansion of organic production [22].

In the institutional framework of organic farming, there is no existence of an organic farmers' association aimed at promoting organic farming advisory and having negotiating and decision-making powers in relation to the state and traders (in particular the retail chains). The establishment of such an organization without state support is, at present, not realistic, as organic farmers do not have the capacities and finances for additional activities themselves.

The inadequately active advisory system appears to be problematic. The conducted analysis showed that organic farming advisory is solely focused on meeting the necessary requirements of the EU and Slovak legislation, with advisory bodies having minimal information on current trends in organic farming in the world. In order to improve production, organic farmers gain information mainly from self-study or from experience from other organic farmers in their surroundings, to a small extent from abroad.

Sufficient information on organic farming is also absent in relation to the market. CCTIA, inspection and certification organizations have their members and their production structures, but they do not have information about organic production or organic products produced and their placement in the market. Similarly, retail chains do not provide information on increasing demand for organic products, but the interviewed retail chains have confirmed that there is an increasing interest in products that have a positive impact on the environment over the last few years, and so the supply of such products is regularly expanding.

It is also negative to note that the Slovak Republic is weakly involved in the memberships and networks associating states supporting organic farming. As the only EU state, it is not a member of the International Federation of Organic Agriculture Movements (IFOAM), the world's largest organic farming organization.

The analysis shows that although there is a real interest of organic farmers in implementing environmentally friendly and consumer-friendly practices, there is no initiative of the state to promote organic farming at the institutional level.

\section{Financial Support of Organic Farming}

The development of organic agriculture in the period 1991-2013 is determined in addition to legislative rules by the amount and structure of financial support, which is mainly influenced by EU financial support. During 2000-2006 there was the SAPARD programme, with priority No. 2 - sustainable rural development, where one of the measures was titled "Agricultural production methods designed to protect the environment and maintain the countryside." The measure only contributed to the financial commitments by a share of $1.29 \%$ compared with $4.29 \%$ planned (ex post evaluation of Rural Development Plan 2004-2006).

After Slovakia joined the European Union, Slovak farmers were able to use financial support from the EU in the form of direct or project payments. Within the framework of the Rural Development Programme 2004-2006, organic farming was classified under Priority 2 "Protection and improvement of the rural environment," Measure 5 "Agri-environmental support" (Table 3). Rural Development Plan 2004-2006 was financed from the Guarantee Section of the European Agricultural Guidance and Guarantee Fund (EAGGF), developed in parallel with Sectoral Operational Programme Agriculture and Rural Development 2004-2006.

The main indicator for the field of organic farming was the area of agricultural land on which organic farming is implemented, with the target of achieving $5 \%$ of the area. The target value of the acreage on $31 / 12 / 2007$ was $5.3 \%$ of agricultural land registered in the Land parcel identification system (10 $650 \mathrm{ha}$ ). According to data of CCTIA, the acreage of cultivated land under organic farming increased between 2004 and 2007 from $2.18 \%$ to $6.14 \%$. In this period 144 projects oriented to organic farming were implemented by farmers before conversion (31.90 thousand ha), and 273 projects (78.76 thousand hectares) by farmers after conversion, so that the interest and preparedness of the Slovak farmers for organic production was visible.

For the next period, 2007-2013, the Rural Development Programme was adopted. Organic farming was supported by the Axis 2 "Improving the environment and the countryside." Axis 2 aimed to improve biodiversity in rural areas and farming systems and forestry with high natural value, maintaining and

Table 3. Subsidies from the Rural Development Plan 2004-2006.

\begin{tabular}{|c|c|c|}
\hline Types of land & $\begin{array}{c}\text { Subsidies during the conversion period } \\
\text { (two years; EUR/ha) }\end{array}$ & $\begin{array}{c}\text { Subsidies after the conversion } \\
\text { (EUR/ha) }\end{array}$ \\
\hline Arable land & 199.16 & 99.58 \\
\hline Orchards and vineyards & 132.78 & 66.39 \\
\hline Vegetables, medicinal, aromatic plants and roots & 331.94 & 165.97 \\
\hline Permanent grassland & 132.78 & 66.39 \\
\hline
\end{tabular}


Table 4. Levels of subsidies from Rural Development Programme 2007-2013.

\begin{tabular}{|c|c|c|}
\hline Types of land & $\begin{array}{c}\text { Subsidies during the conversion period } \\
\text { (two years; EUR/ha) }\end{array}$ & $\begin{array}{c}\text { Subsidies after the conversion } \\
\text { (EUR/ha) }\end{array}$ \\
\hline Arable land & 218.12 & 152.69 \\
\hline Orchards and vineyards & 705.87 & 529.44 \\
\hline Vegetables, medicinal, aromatic plants and roots & 958.77 & 671.15 \\
\hline Permanent grassland & 137.39 & 96.16 \\
\hline
\end{tabular}

improving the quality of groundwater and surface water, maintaining and improving the quality of agricultural and forest land and mitigating the effects of climate change. Organic farming support was implemented under the measure "Agri-environmental payments" and the sub-measure "Organic farming". The total contribution of the measure Agri-environmental payments was set at 341,130,543 EUR for the whole programming period, which represents more than $13 \%$ of the total contribution of the European Agricultural Fund for Rural Development for the programming period 2007-2013. The amount of support is determined as a compensation for loss of revenue from reduced production and additional costs resulting from the conditions of this sub-measure of EU and national legislation (Table 4).

The summary report for the project measuring the Rural Development Programme 2007-2013 on 31.12.2012 shows that to support the agri-environmental measures, including organic farming, 158,037,424 EUR was used (101\% of total expenditure provided for Rural Development Programme 2007-2013 for the measure).

It can be said that the development of organic farming was positively launched, but the state's policy interventions and its instruments have been slowing the motivation of organic farmers since that time.

Under the new programming period 2014-2020, Regulation (EU) No. 1305/2013 of the European Parliament and of the Council on support for rural development by the European Agricultural Fund for
Rural Development (EAFRD) and repealing Council Regulation (EC) No. 1698/2005 has been adopted, which established a framework for the EU support for rural development, including organic farming (Article 29). Following the Regulation, the EU-Slovakia Partnership Agreement 2014-2020 [23] was signed and organic farming became a part of the program priorities in two parts of the document:

- Section 1.3.1.3 TC 3 "Increasing the competitiveness of small and medium enterprises," the agricultural sector (for the EAFRD) and the fisheries and aquaculture sector (in the case of the ENRF) expresses the need to increase the share of domestic production with higher added value, through organic farming.

- Section 1.3.4.3 TC 6 "Preservation and protection of the environment and support for resource efficiency," in which support for organic farming is seen as a tool for biodiversity conservation and the environment.

Under the Partnership Agreement 2014-2020, the Rural Development Programme 2014-2020 (hereinafter RDP 2014-2020) [24] has been developed, which includes the measure "Organic farming" (M11), which aims to improve the state of the environment and to improve the quality of life and rural attractiveness through land management and organic farming practices, as well as an increase in the share of domestic production and higher product quality.

Under the measure, farmers can obtain, as in previous years, the following:

Table 5. Levels of subsidies from Rural Development Programme 2014-2020.

\begin{tabular}{|c|c|c|c|}
\hline \multicolumn{2}{|c|}{ Types of land } & $\begin{array}{l}\text { Subsidies during the conversion period } \\
\text { (EUR/ha) }\end{array}$ & $\begin{array}{l}\text { Subsidies after the conversion } \\
\text { (EUR/ha) }\end{array}$ \\
\hline \multicolumn{2}{|c|}{ Arable land } & 153 & 153 \\
\hline \multicolumn{2}{|c|}{ Vegetables, medicinal, aromatic plants and roots } & 529 & 529 \\
\hline \multicolumn{2}{|c|}{ Potatoes } & 290 & 290 \\
\hline \multirow{2}{*}{ Orchards - intensive } & Productive & 671 & 671 \\
\hline & Young & 420 & 420 \\
\hline \multicolumn{2}{|c|}{ Orchards - other } & 330 & 330 \\
\hline \multirow{2}{*}{ Vineyards } & Productive & 671 & 671 \\
\hline & Young & 420 & 420 \\
\hline \multicolumn{2}{|c|}{ Permanent grassland } & 96 & 96 \\
\hline
\end{tabular}


- Payment for transition to organic farming practices and methods (two years).

- Payment for the maintenance of organic farming practices and methods (five years with the option of annual renewal).

Both payments are their second annual compensation per hectare of agricultural land per type of land in the commitment. Total public expenditure under the measure amounts to 90,000,000 EUR.

Table 5 shows that compared to previous programming periods (Tables 3 and 4), conversion payments and organic farming are identical. This may cause a drop in willingness to engage in the commitment as the shift from conventional agricultural production to conversion represents a significant loss of earnings for the farmer (about 30\%), but the market cannot pay for it in that period because the farmer in conversion cannot use the organic farming label.

Similarly, some types of support are lower in previous years, which can also cause demotivation of farmers to enter into commitments under the measure.

From the point of view of setting up, it is not logical to justify the payment on intensive orchards in terms of ecologization. RDP 2014-2020 shows that a farmer under a commitment to "orchards-intensive" can plant an average of two to three times the number of individuals per hectare compared to a farmer who has committed to a payment for "orchards-other." From the point of view of economic yields, a farmer with intensive orchards will receive two to three times higher yields and then profits. However, the payment on intensive orchards compared to other orchards is two times higher for productive orchards and three times higher for young orchards. However, during a direct interview with the CCTIA staff, the setting of this payment as well as its height was not justified.

As the results show, despite the fact that the state has set up financial support for organic farming, Table 1 and Figure 2 do not show any significant willingness to enter into commitments, and there is also a high percentage of organic farmers who are getting out of the commitment.

In terms of support for organic farming, up to $87.17 \%$ of organic farmers received payments between the years 2015-2016 to maintain organic farming practices and methods. This payment is only an additional payment for organic farmers, since each of them receives a single area payment and payments for non-project measures.

On the other site, the findings show that, in the programming period 2014-2020, the interest in payment for the transition to organic farming practices and methods has declined. Only $38.1 \%$ of organic farmers registered at the CCTIA in 2015 who were converting at the time of receiving the single application for conversion in $2016^{6}$ requested payment for the transition

United application for payment shall be submitted to the Agricultural Paying Agency by 15 May of the calendar year. to organic farming practices and methods. None of the organic farmers registered at the CCTIA in 2016 who managed to submit applications to APA in 2016 has requested this payment.

Additional interviewing of organic farmers has shown that the payment for transition to organic farming practices and methods is not motivating for conventional farmers. On the contrary, these farmers use payments for other agri-environmental measures. In this context, the policy of determining the amount of individual payments for environmental purposes under M10 "Agri-environment climate measures" (AEKO) and M11 "Organic Agriculture" is not understandable in terms of state policy. Measures M10 AEKO introduced a measure of integrated production in orchards, vineyards and vegetable production, whereby the farmer can undertake agro-technical procedures, where he or she reduces the burden for soil and water, primarily reducing the amount of mineral fertilizers, pesticides, herbicides and fungicides into the soil. The farmer will receive a payment for the fulfilment of the commitment that is twice as high as payment under M11 Organic Farming if the farmer is forbidden to use any chemical input into the soil. In terms of yields, however, an organic farmer will achieve a yield of about $30 \%$ less compared to a farmer in integrated production. At the same time, organic farmers are not allowed to use organic farming labels, which ultimately leads to more significant profit losses.

For this reason, farmers are entering other AEKO commitments during the conversion. However, they experience stricter rules on organic farming under these commitments. After two years of conversion, they are entitled to designate their production as organic. This potentially increases the market price of their production. With lower costs and lower yields, organic farmers have on average the same profit as conventional farmers - in some cases higher or lower [25].

Data from finstat.sk and zisk.sk show that out of 294 organic farmers (legal entities), there are up to 94 subjects (31.97\%) in the longer-term loss. Long-term loss means the impossibility for organic farmers to invest in innovation and technology for their production. The survey revealed that the organic farmers compensate the loss in organic production by using profits from conventional production.

Under RDP 2014-2020, it is also possible to obtain additional funding within the measures:

- Support for training actions and skills acquisition.

- Support for demonstration and information actions focusing on individual areas, e.g., on ecology.

These calls for proposals have not yet been opened.

Motivational Incentives/Barriers to the Development of Organic Farming

For each farmer, the transition from conventional to organic agricultural production is a substantial interference in business activities. As reported by [26], 
Table 6. Recommendation for supporting organic farming in the Slovak Republic.

\begin{tabular}{|c|c|c|}
\hline Development steps & Reality in conditions of SR & Recommendations \\
\hline $\begin{array}{l}\text { Establishment of organic farming } \\
\text { community }\end{array}$ & $\begin{array}{l}\text { increase of number, interest and } \\
\text { readiness of farmers to enter the organic } \\
\text { farming system, but on average } 56.1 \% \text { of } \\
\text { organic farmers exit the system after the } \\
\text { expiration of } 5 \text { years commitment; } \\
\text { - developing community of organic } \\
\text { farmers (organization EKOTREND) }\end{array}$ & $\begin{array}{l}\text { - } \text { setting up of a comprehensive and } \\
\text { continuous support for organic farming; } \\
\text { - decrease of bureaucracy }\end{array}$ \\
\hline $\begin{array}{l}\text { Political recognition of organic } \\
\text { farming standards and certification } \\
\text { as a basis for distributing products } \\
\text { and recruiting farmers }\end{array}$ & $\begin{array}{l}\text { - legislation formally copy the EU legal } \\
\text { acts; } \\
\text { - interlinking of the individual legal acts; } \\
\text { - } \text { discontinuity of political framework for } \\
\text { organic farming; } \\
\text { - } \text { absence of conceptual approach }\end{array}$ & $\begin{array}{l}\text { - to create a concept and action plan of } \\
\text { organic farming; } \\
\text { - to interlink the legal acts for organic } \\
\text { farming with legal acts for other areas } \\
\text { of entrepreneurship }\end{array}$ \\
\hline $\begin{array}{l}\text { Introduction of financial support for } \\
\text { organic farmers }\end{array}$ & $\begin{array}{l}\text { - decrease of financial support for organic } \\
\text { farmers and farmers in conversion; } \\
\text { - cancellation of financial support for } \\
\text { organic farmers dealing with animal } \\
\text { production }\end{array}$ & $\begin{array}{l}\text { - higher support for organic farmers and } \\
\text { farmers in conversion; } \\
\text { - other stimuli for organic farming with } \\
\text { a financial impact on organic farmers } \\
\text { (e.g. tax benefits, sale support, etc.) }\end{array}$ \\
\hline $\begin{array}{l}\text { Positive involvement of general } \\
\text { farmer organisations }\end{array}$ & $\begin{array}{l}\text { - general farmers organisations are not } \\
\text { involved and supported }\end{array}$ & $\begin{array}{l}\text { - support for organic farming through } \\
\text { involvement of the general farmers } \\
\text { organisations }\end{array}$ \\
\hline $\begin{array}{l}\text { Development of organic food } \\
\text { market mechanism }\end{array}$ & $\begin{array}{l}\text { - weak state support for the organic } \\
\text { market; } \\
\text { - } \text { absence of a Slovak organic label; } \\
\text { - weak organic processing industry }\end{array}$ & $\begin{array}{l}\text { - } \begin{array}{l}\text { stimulation of state organic market } \\
\text { development; }\end{array} \\
\text { - stimulation of organic processing } \\
\text { industry and related industries alongside } \\
\text { the whole production channel }\end{array}$ \\
\hline $\begin{array}{l}\text { Establishment of an institutional } \\
\text { setting in the form of administrative } \\
\text { committee, umbrella organisation, } \\
\text { advisory board or other type of } \\
\text { discussion arena to facilitate the } \\
\text { necessary coordination among } \\
\text { farming community, agricultural } \\
\text { policy and the food market }\end{array}$ & $\begin{array}{l}\text { - absence of a platform for organic } \\
\text { farmers (beside the EKOTREND, what } \\
\text { is a NGO), resulting in non-functioning } \\
\text { advisory service; } \\
\text { - insufficient data on organic farmers. }\end{array}$ & $\begin{array}{l}\text { - } \quad \text { creation and support for a platform for } \\
\text { organic farmers; } \\
\text { - improvement of advisory service in the } \\
\text { area of organic farming; } \\
\text { - improvement of a database with data } \\
\text { about the organic farming. }\end{array}$ \\
\hline
\end{tabular}

the more specialized the agricultural company, the more complex and longer the conversion is to achieve the necessary sustainable parameters. Conversion aims to eliminate the influence of negative impacts of previous agricultural activities on agricultural land, landscape and environment, and implement management practices, which respect the principles of organic farming.

When deciding on the transition to organic farming, the motivation of the farmer regarding commitment plays an important role. The questionnaire survey showed that the main motivation for farmers (91\%) is the financial benefit derived from increased funding from RDP. Some farmers also decided on organic production because of the availability of land in areas with limited inputs. $22.5 \%$ of farmers indicated that their motivation is the protection of the environment, reduced cost of fertilizers, chemicals and other equipment (e.g. tank, sprayers of artificial fertilizers, etc.). $10.3 \%$ of respondents indicated that the reason for the conversion is the possibility to offer their organic products abroad. Such farmers, therefore, did not reflect in any way the quality of the conditions of organic farming in Slovakia.
Based on the responses from the farmers, the main barriers are:

- The absence of a formalized association of organic farmers aimed at promoting organic farming in terms of advisory and negotiation in relation to the state and traders.

- Weak support of the promotion and marketing of organic farming in relation to the state and consumers.

- High bureaucratic burden, in particular in relation to CCTIA, certification and control bodies and APA.

- Weak and even non-existent processing industry for organic farming in some areas - interviewed organic farmers have said that livestock production is so weak that they are forced to sell their products with short expiration (milk, meat) to traders for conventional product prices, and also the lack of organic slaughterhouses, processors or transport of products at an available distance from organic farmers.

Interviewed organic farmers with higher acreages claimed that organic farming is functioning as 
optimizing production while using permanent grasslands, but in terms of profits, this production is only complementary to the profits from conventional production. Several organic farmers in plant production have contracted organic production for export, as in the Slovak Republic this plant production will be bought at an increased price by the processors (mills, breweries) [27].

\section{Recommendations for Support of Organic Farming in the Slovak Republic}

Based on the concept as defined by [9] we can formulate the recommendations that are prerequisites for effective implementation of organic farming in Slovak conditions (Table 6).

\section{Conclusions}

Organic farming is a concept of sustainable agriculture, which at the same time creates added value in terms of improving the quality of life of the population and the countryside. Slovakia has ideal natural conditions for this type of farming. This paper, therefore, assessed the fundamental support of the state in the area of legislation, policy and institutional and financial instruments to support organic farming. Research results have shown that the main incentive for organic farming is financial support, which has been implemented through the EU financial instruments since 2004. Although increased funds can encourage farmers to convert from conventional to organic production, they cannot be the only incentive to maintain organic production. On average, $56.1 \%$ of organic operators included in organic production between the years 2004 and 2016 have asked the CCTIA to cancel their registration as organic operators. This status represents a threat that the state should address and initiate steps leading to more intense and more targeted support for organic farming.

From the point of view of policy and legislation, the state would require a comprehensive concept of organic farming to be prepared and to link legal regulation to legislation on business support. In line with the legislation, the state should initiate the establishment of an umbrella association of organic farmers to contribute to the visibility of organic farmers on the market and to improve the status of organic farmers in relation to state and traders. The state should also take care to improve advisory services and improve the awareness and accessibility of the latest knowledge on organic farming, for example by engaging in international organic farming organizations or promoting organic farming in organic farming and networks of organic farmers.

Funds for organic farming in the programming period 2014-2020 are unduly allocated to organic farmers carrying out plant production, although organic animal production is carried out by over $80 \%$ of all organic farmers. Equally unjustifiable are the amounts of single payments for organic farming, which are lower in comparison to other payments for less demanding environmentally friendly practices. The state should review the importance of organic farming for the Slovak Republic and financially support organic farmers to a larger extent.

Based on the results of the research, it can be concluded that the development of organic farming has been positively launched, but currently it is stagnating mainly due to the state's intervention in the policy area and its instruments.

\section{Acknowledgements}

The author expresses her gratitude for all the support provided by the Department of Law, Faculty of European Studies and Regional Development, SUA Nitra for this research through a project of the Jean Monnet Centre of Excellence "EU land policy - the pathway towards sustainable Europe," No. 542600-LLP1-2013-1SK-AJM-PO.

\section{Conflict of Interest}

The authors have not declared any conflict of interest.

\section{References}

1. COSTA C.A., CORREIA H.E., CORREIA P., COSTA D., GAIAO D., GUINÉ R., COELHO C., COSTA J.M., MONTEIRO A., OLIVEIRA J., PINTO A., RODRIGUES P., SERRANO J.M.C., GUERRA L.T., SEEDS C., COLL C., MACDONALD J., RADICS L., SOYLU S., ARSLAN M., TÓTHOVÁ M., TÓTH P., BASILE S. Eco New Farmer. Introduction to ecological farming. EOSA: Vigo, Spain, pp. 325, 2016. Available online: http://www. econewfarmers.eu/wp-content/uploads/DOCUMENTOS/ ebook-sk.pdf (accessed on 26-10-2017).

2. SLIGH M., CIERPKA T. Organic Farming. An International History. In LOCKERETZ W. Cromwell Press: Trowbridge, United Kingdom, 30, 2007.

3. VOGT G. Organic Farming. An International History. In Lockeretz W. Cromwell Press: Trowbridge, United Kingdom, 9, 2007.

4. FOOD AND AGRICULTURAL ORGANISATION OF THE UNITED NATIONS/WORLD HEALTH ORGANISATION. Codex Alimentarius Commission. 1999. Available online: http://www.fao.org/organicag/oafaq/oa-faq1/en/ (accessed on 30-10-2017).

5. INTERNATIONAL FEDERATION OF ORGANIC AGRICULTURE MOVEMENTS (IFOAM). Organics International. 2017. Available online: https://www.ifoam. bio/sites/default/files/poa_english_web.pdf (accessed on 30-10-2017).

6. Council Regulation (EC) No. $834 / 2007$ on organic production and labelling of organic products and repealing Regulation (EEC) No. 2092/91, 2007. 
7. MARKUSZEWSKA I., KUBACKA M. Does the organic farming work in favour of protecting the natural environment? A case of Poland. In Land Use Policy, Volume 67, 498, 2017.

8. CILLE M. Green Agriculture in Hungary: The Factors of Competitiveness in Organic Farming. Sustainable Economic Development: Green Economy and Green Growth. Springer International Publishing, AG, 83, 2017.

9. MICHELSEN J. et al. In STOEAVA S. Opening the „Black Box" of Organic Agriculture in Bulgaria: the Problem with Top-down Institutional Development. Eastern European Countryside, DOI: 10.1515/eec-2016-0005, 2016.

10. PALŠOVÁ L., SCHWARCZOVÁ L., SCHWARCZ P., BANDLEROVÁ A. The Support of Implementation of Organic Farming in the Slovak Republic in the Context of Sustainable Development. In Procedia - Social and Behavioural Sciences, Volume 110, 520, 2014.

11. WILLIAMS M., LAW D., SCHMITY J. Organic Crop Production. University of Kentucky: Lexingtone, United States of America, 2011. Available online: http://www. uky.edu/Ag/NewCrops/introsheets/organicproduction.pdf (accessed on 07-08-2017).

12. VANKOVÁ V., BALÁŽ I. Ecology of environmental agricultural systems. UKF: Nitra, Slovak Republic, 120, 2005 [In Slovak].

13. MINISTRY OF AGRICULTURE AND RURAL DEVELOPMENT OF THE SLOVAK REPUBLIC. Final report of ex-post evaluation of Rural Development Plan 2004-2006. 2007. Available online: http://mpsr.sk/index. php?navID $=47 \&$ sID $=43 \&$ navID2 $=803$ (accessed on 09-122017).

14. MINISTRY OF AGRICULTURE AND RURAL DEVELOPMENT OF THE SLOVAK REPUBLIC. Slovakia - Rural Development Programme 2007-2013. 2007. Available online: http://www.apa.sk/prv-vlastnydokument (accessed on 30-10-2017).

15. MINISTRY OF AGRICULTURE OF THE SLOVAK REPUBLIC. Action Plan for the Development of Organic Agriculture, MP SR: Bratislava, Slovak Republic. 2005.

16. GEODESY, CARTOGRAPHY AND CADASTRE AUTHORITY OF THE SLOVAK REPUBLIC. Statistical Yearbook on the Soil Fund in the Slovak Republic according to cadastre data on 31.01.2017. Geodesy, Cartography and Cadastre Authority of the Slovak Republic: Bratislava, Slovak Republic, pp. 130, 2017 [In Slovak].
17. Central Control and Testing Institute in Agriculture, 2017. Available online: http://www.uksup.sk/odbor-ekologickejpolnohospodarskej-vyroby/ (accessed on 15-11-2017).

18. KOZÁKOVÁ J., PAŠKA L', LANČARIČ D., SAVOV R. Organic farming. SPU: Nitra, Slovak Republic, 170, 2012 [In Slovak].

19. MINISTRY OF AGRICULTURE AND RURAL DEVELOPMENT OF THE SLOVAK REPUBLIC. Concept of Development of Slovak Agriculture for the years 2013-2020. 2013. Available online: www.mpsr.sk/ download.php?fID=7015 (accessed on 30-10-2017).

20. SZOVICS P. Financing of agricultural advisory system in the world. In Advisory in agri food sector - significant strategic and intensification tool. Agroinštitút: Nitra, Slovak Republic, 243, 2001 [In Slovak].

21. BERGLUND M., DWORAK T. Integration of water management advisory services to farmers - Guide for public administration, 55, 2010 [In Slovak].

22. INTERNATIONAL FEDERATION OF ORGANIC AGRICULTURE MOVEMENTS. New impulses for continued growth: latest statistics on organic farming worldwide By Research Institute of Organic Agriculture and the International Federation of Organic Agriculture Movements. 2013. Available online: http://www.ntxenews.com/artman/publish/article_84121.shtml (accessed on 26-08-2017).

23. GOVERNMENT OF THE SLOVAK REPUBLIC. Partnership agreement of the SR. 2014. Available online: http://www.partnerskadohoda.gov.sk/zakladnedokumenty/ (accessed on 10-12-2017).

24. MINISTRY OF AGRICULTURE AND RURAL DEVELOPMENT OF THE SLOVAK REPUBLIC. Slovakia - Rural Development Programme 20142020. 2015. Available online: http://www.apa.sk/index. php?navID=496 (accessed on 10-12-2017).

25. KONEČNÝ M. Agriculture in the enlarged EU: the risks and opportunities. CEPA, Friends of the Earth Europe, 80, 2004 [In Slovak].

26. LACKO-BARTOŠOVÁ M. Sustainable and ecological agriculture. SPU: Nitra, Slovak Republic, 575, 2005 [In Slovak].

27. ŠIMČÁK P., HRONEC O., STEHLO P., WOŽNIAK L., ČARNICKÝ, Š. Economy of bio food. SPU: Nitra, Slovak Republic, 168, 2003 [In Slovak]. 